\title{
TINJAUAN HUKUM PELAKSANAAN HARMONISASI RANCANGAN PERATURAN BUPATI PADA BAGIAN HUKUM SEKRETARIAT DAERAH KABUPATEN BANGGAI
}

\author{
${ }^{1}$ Rizka Ifanka Amir, ${ }^{2}$ Nirwan Moh. Nur, ${ }^{3}$ Asis Harianto \\ ${ }^{1,2,3}$ Fakultas Hukum Universitas Muhammadiyah Luwuk \\ ${ }^{1}$ rizkaamir09@gmail.com, ${ }^{2}$ nnirwanmnur@yahoo.co.id, ${ }^{3}$ asis_harianto@yahoo.co.id
}

\begin{abstract}
ABSTRAK
Penelitian ini bertujuan mengatahui pelaksanaan harmonisasi rancangan Peraturan Bupati oleh Bagian Hukum Sekretariat Daerah Kabupaten Banggai serta faktor-faktor yang mempengaruhinya. Adapun jenis penelitian yang digunakan adalah penelitian hukum empiris. Dalam Pelaksanaan harmonisasi rancangan peraturan bupati yang dilakukan oleh Bagian Hukum Sekretariat Daerah Kabupaten Banggai tersebut berawal dari pemrakarsa dalam hal ini organisasi perangkat daerah (Dinas atau Badan) menyusun draft rancangan Perbup kemudian diajukan kepada Bagian Hukum untuk dikoreksi dan diharmonisasi terkait dengan keserasian dengan peraturan perundang-undangan terkait dan kesesuaian dengan tata cara penyusunan produk hukum daerah. Setelah itu hasil rancangan Perbup yang telah diperbaiki diajukan atau disampaikan kepada Bupati melalui Sekretaris Kabupaten untuk dilakukan paraf koordinasi. Adapun faktor-faktor yang mempengaruhinya meliputi faktor yang mendukung yaitu faktor hukum, dan koordinasi. Sedangkan faktor penghambat yaitu penguasan materi oleh pemrakarsa dan Sumber Daya Manusia.
\end{abstract}

Kata kunci: Harmonisasi, Peraturan Bupati

\section{ABSTRACT}

This study aims to determine the implementation of the harmonization of the draft Regent's Regulation by the Legal Section of the Banggai Regency Regional Secretariat and the factors that influence it. The type of research used is empirical legal research. In the implementation of the harmonization of the regent's draft regulation carried out by the Legal Section of the Banggai Regency Regional Secretariat, it started with the initiator in this case the regional apparatus organization (Department or Agency) preparing a draft Perbup draft which was then submitted to the Legal Department for correction and harmonization related to compatibility with laws and regulations. related invitations and conformity with the procedures for the preparation of regional legal products. After that, the results of 
the revised Perbup draft are submitted or submitted to the Regent through the Regency Secretary for initial coordination. The factors that influence it include supporting factors, namely legal factors, and coordination. While the inhibiting factor is the mastery of the material by the initiator and Human Resources.

Keywords: Harmonization, Regent Regulation

\section{Latar Belakang}

Negara Indonesia adalah negara hukum, Hal tersebut sebagaimana yang tertuang pada Pasal 1 ayat (3) UndangUndang Dasar Negara Republik Indonesia Tahun 1945 (UUD NRI 1945). Sebagai negara hukum, tentunya seluruh aspek berbangsa dan bernegara harus berlandaskan hukum. Hukum yang dimaksud adalah untuk keadilan bagi seluruh rakyat Indonesia.

Untuk menyelenggarakan tugastugas pemerintahan dilaksanakan oleh pemerintah dan pemerintah daerah provinsi dan kabupaten/kota. Hal ini sebagaimana mengacu pada konsep desentralisasi penyelenggaraan pemerintahan Indonesia. Desentralisasi merupakan penyerahan sebagaian kekuasaan pemerintahan oleh Pemeritah kepada daerah otonom berasaskan otonomi. Untuk melaksanakan kekuasaan pemerintahan tersebut pemerintahan daerah mempunyai kewenangan membentuk peraturan perundang-undangan, sebagai instrumen penyelenggaraan otonomi. Hal ini sebagaimana yang tertuang dalam Pasal 18 ayat (6) UUD NRI 1945, bahwa pemerintahan daerah mempunyai kewenangan menetapkan peraturan daerah dan peraturan lainnya untuk melaksanakan otonomi dan tugas pembantuan.

Otonomi Daerah menurut Faisal Abdullah (2009:35) “merupakan praktik tata penyelenggararan pemerintahan daerah (local government) mempunyai kewenangan untuk mengurus dan mengatur rumah tangganya sendiri". Pelaksanaan otonomi daerah menurut Sri Magdalena Hutabalian (2015:74) mewajibkan setiap daerah mempunyai kewenangan untuk mengatur dan mengelola seluruh potensi daerah juga dalam pembentukan produk hukum sesuai dengan kondisi daerahnya masing-masing. Sedangan menurut Maria Farida Indrati S (Dodi Jaya Wardana, 2017:55) perundang- 
undangan merupakan proses pembentukan peraturan Negara baik Mertokusumo (2006:11) dalam tingkat pusat maupun ditungkat daerah. merumuskan norma hukum yang Selain itu peraturan perundang- konkret pada peraturan perundangundangan adalah segala peraturan undangan harus mengacu pada asas Negara yang merupakan hasil hukum. Asas hukum dimaksud meliputi pembentukan peraturan baik tingkat asas-asas pembentukan peraturan pusat maupun tingkat daerah. perundag-undangan yang baik. Asas Berdasarkan Pasal 236 Undang-Undang tersebut digunakan pada saat Nomor 23 Tahun 2014 tentang penyusunan isi peraturan agar Pemerintahan Daerah (UU No. 23 menghasilkan bentuk, susunan dan Tahun 2014) dalam rangka melaksanakan otonomi daerah dan tugas pembantuan, daerah membentuk peraturan daerah (Perda).

Perda yang dibentuk oleh daerah hanya berlaku pada wilayah yuridiksi daerah tersebut. Namun dalam membentuk Perda tidak boleh bertentangan dengan peraturan perundang-undangan yang lebih tinggi berdasarkan hierarki peraturan perundang-undangan yang diatur dalam Undang-Undang Nomor 12 Tahun 2011 tentang Pembentukan Peraturan Perundang-undangan. Sehingga dalam membentuk Perda yang dapat memenuhi kebutuhan masyarakat maka sistematika, norma dan standar mengacu pada undang-undang tersebut, selain undangundang pemerintahan daerah.

metode yang tepat, serta mengikuti prosedur pembentukan yang tepat.

Untuk melaksanakan Peraturan Daerah (Perda) dan juga perintah peraturan perundang-undangan diatasnya, Kepala Daerah menetapkan Peraturan Kepala Daerah (Perkada). Dalam implementasinya istilah Perkada untuk provinsi disebut Peraturan Gubernur, sedangkan untuk kabupaen/kota disebut Peraturan Bupati atau Peraturan Walikota. Sehingganya penyelenggaraan pemerintahan daerah diera otonomi menghasilkan berbagai Peraturan Daerah (Perda) dan Peraturan Kepala Daerah (Perkada).

Begitu juga penyelenggaan pemerintahan daerah kabupaten berbagai Peraturan Daerah kabupaten (Perda) dan Peraturan Bupati (Perbup) 
menghiasi pelaksanaan otonomi dan tugas pembantuan dalam rangka meningkatkan kesejahteraan masyarakat di daerah kabupatennya. Hal ini berkonsekuensi dengan lahirnya banyak Perda maupun Perbup. Banyak produk hukum daerah tersebut bisa saja menghasilkan produk hukum daerah yang bermasalah.

Namun terkait dengan Peraturan Bupati (Perbup), dalam penelitian ini menjadi topik dikarenakan proses pembentukan Peraturan Bupati tidak melalui Lembaga Dewan Perwakilan Rakyat Daerah (DPRD), namun ditetapkan sepihak oleh Pemerintah Daerah Kabupaten dalam hal ini Bupati. Sebagaimana dalam Pasal 42 Peraturan Menteri Dalam Negeri Nomor 120 Tahun 2018 tentang Perubahan atas Peraturan Menteri Dalam Negeri Nomor 80 Tahun 2015 tentang Pembentukan Produk Hukum Daerah (Permendagri No. 120 Tahun 2018) menyebutkan bahwa organisasi perangkat daerah sebagai pemrakarsa sesuai dengan materi Peraturan Bupati tersebut.

Pimpinan Organisasi Perangkat Daerah (OPD) sebagai pemrakarsa rancangan Peraturan Bupati tentunya memiliki keterbatasan, karena dalam
OPD tidak memiliki tenaga ahli atau bidang tersendiri untuk menyusun Perbup tersebut. Untuk mengatasi lahirnya produk-produk hukum daerah khususnya perbup yang bermasalah maka harus dilakukan upaya preventif sebagai langkah awal melakukan penyaringan Perbup yang tidak semestinya, agar menjadi efektif dimasyarakat. Untuk itulah sebelum rancangan Peraturan Bupati tersebut sebelum ditetapkan oleh Bupati terlebih dahulu dilakukan pembahasan atau harmonisasi pada Bagian Hukum Pemerintah Daerah Kabupaten. Hal ini sebagaimana yang tercantum pada Pasal 42 ayat (3) Permendagri No. 120 Tahun 2018.

Begitu juga yang terjadi pada Pemerintah Daerah Kabupaten Banggai. Dalam menjalankan otonomi daerah dan tugas pembantuan Pemerintahan Daerah menerbitkan Perda dan Perbup. Lebih khusus Peraturan Bupati (Perbup), pada tahun 2019 telah ditetapkan 55 Peraturan Bupati dan tahun 2020 ditetapkan sebanyak 51 Peraturan Bupati. Sebagaimana tahapan pembentukan yang diatur dalam Permendagri No. 120 Tahun 2018, bahwa sebelum Perbup ditetapkan oleh 
Bupati terlebih dahulu dilakukan merumuskan dan menyusun konsep pembahasan atau harmonisasi pada rancangan Peraturan Daerah, Peraturan Bagian Hukum Sekretariat Daerah Kabupaten Banggai.

Harmonisasi yang dilakukan oleh Bagian Hukum Sekretariat Daerah Kabupaten Banggai sesuai dengan Peraturan Bupati Banggai Nomor 5 Tahun 2017 tentang Uraian Tugas, Fungsi dan Tata Kerja Sekretariat Daerah, yang merupakan Peraturan Pelaksana dari Peraturan Daerah Kabupaten Banggai Nomor 4 Tahun 2016 tentang Pembentukan dan Susunan Perangkata daerah Kabupaten Banggai. Berdasarkan Peraturan Bupati No 5 Tahun 2017 pada Pasal 18 ayat (3) huruf e menjelaskan bahwa Kepala bagian Hukum dan Perundang-undangan mempunyai tugas melaksanakan kajian hukum, evaluasi dan pengawasan pelaksanaan peraturan perundangundangan khusunya produk hukum daerah.

Selain itu dalam teknik operasional pelaksanaan tugas Bagian Hukum terdapat Kepala sub Bagian Perundang-undangan dan Implementasi Hukum yang mempunyai tugas melaksanakan penelitian, pengharmonisasian, pengkajian, Bupati, Keputusan Bupati dan Instruksi Bupati. Berdasarkan ketentuan tersebut menunjukan bahwa untuk melakukan harmonisasi rancangan Peraturan Bupati dari pemrakarsa. Harmonisasi dilakukan oleh Bagian Hukum dan PerundangUndangan lebih khusus pada Kepala sub Bagian Perundang-undangan dan Implementasi Hukum. Dari observasi awal yang dilakukan penulis bahwa Bagian Hukum dalam melakukan harmonisasi selama ini terdapat beberapa rancangan Peraturan Bupati yang keliru merumuskan landasan sosiologis, politis dan yuridis.

Untuk itu keberadaan Bagian Hukum dan Perundang-undangan dalam mengharmonisasikan rancangan Peraturan Bupati dari pemrakarsa dalam hal ini OPD sangat penting untuk membuat layak rancangan Perbup ditetapkan oleh Bupati dan akan memberi rmanfaat untuk masyarakat.

\section{Metode Penelitian}

Jenis penelitian ini adalah yuridis empiris yaitu penelitian yang menggunakan data primer yang bersumber langsung dari subjek penelitian yang akan diteliti. Penelitian 
ini dilakukan pada Bagian bagian Hukum dan Perat uran PerundangUndangan Sekretariat Daerah Kabupaten Banggai. Adapun teknik analisis data yang digunakan dalam penulisan ini adalah deskriptif kualitatif.

\section{Hasil dan Pembahasan}

\section{A. Pelaksanaan \\ Harmonisasi \\ Rancangan Peraturan Bupati oleh \\ Bagian Hukum Sekretariat \\ Daerah Kabupaten Banggai}

Harmonisasi

rancangan

peraturan bupati merupakan proses

untuk menyelaraskan dan menyerasikan rancangan peraturan bupati dengan peraturan perundang-undangan yang lain, selain itu, untuk menghindari adanya tumpang tindih dalam pengaturanya. Menurut Endang Sumiarni (Soegiyono, 2015:4) harmonisasi merupakan proses mengkaji persesuaian antara peraturan perundangundangan secara horisontal atau yang sederajat dalam peraturan yang sedang berlaku. Sehingganya dalam penyusunan peraturan perundang-undangan harus memastikan bahwa materi yang diatur dalam peraturan perundang-undangan tidak bertentangan dengan peraturan perundang-undangan diatasnya. (Hermi
Sari BN, Galang Asmara, Zunnuraeni, 2020:319).

Sedangkan menurut Peraturan Menteri Hukum dan hak Asasi Manusia Nomor 20 tahun 2015 Tentang Tata Cara dan Prosedur Pengharmonisasian, Pembulatan, dan Pemantapan Konsep Rancangan Peraturan PerundangUndangan (Permenkumham No. 20 Tahun 2015) bahwa "Pengharmonisasian Konsepsi Rancangan Peraturan Perundangundangan adalah proses penyelarasan substansi Rancangan Peraturan Perundang-Undangan dan teknik penyusunan Peraturan Perundangundangan, sehingga menjadi Peraturan Perundang-undangan yang merupakan satu kesatuan yang utuh dalam kerangka sistem hukum nasional."

Begitu juga dengan produk hukum daerah yang salah satunya adalah peraturan kepala daerah ayau lebih spesifik adalah Peraturan Bupati. Sebelum rancangan peraturan bupati tersebut ditetapkan terlebih dahulu dilakukan harmonisasi. Harmonisasi dilakukan oleh bagian hukum sekretariat daerah kabupaten.

Dalam tulisan ini, merupakan hasil penelitian yang dilakukan pada 
Pemerintah Daerah Kabupaten Banggai dalam hal ini Bagian Hukum Sekretariat Daerah Kabupaten Banggai dalam melakukan harmonisasi rancangan peraturan bupati. Sebelum mengkaji tentang pelaksanaan harmonisasi peraturan bupati di Kabupaten Banggai, terlebih dahulu disajikan data jumlah rancangan peraturan bupati yang dilakukan harmonisasi yaitu dalam kurun waktu dari tahun 2018 sampai dengan bulan Mei 2021 jumlah rancangan peraturan bupati (Perbup) yang dilakukan harmonisasi oleh Bagian Hukum SETDA Kabupaten Banggai berjumlah 190 rancangan, dengan jumlah rancangan yang terbitkan berjumlah 187 rancangan dan jumlah rancangan Perbup yang ditolak berjumlah 3 rancangan.

Proses harmonisasi yang dilakukan Bagian Hukum SETDA Kabupaten Banggai menurut Farid Hasbullah Karim, Kepala Bagian Hukum Setda Kabupaten Banggai (wawancara 12 Juli 2021) bahwa "harmonisasi rancangan Perbu adalah untuk mensingkronkan norma-norma dan kaidah-kaidah dalam penyusunan produk hukum. Norma yg berkaitan dgn legal standing sedangkan kaidah berkaitan dengan tata cara penyusunan." Hal tersebut sebagaimana juga yang diatur dalam Permenkumham No. 20 Tahun 2015 pada Pasal 3, yaitu "Pengharmonisasian Konsepsi Rancangan Peraturan Perundangundangan dilakukan dengan tujuan untuk:

a. menyelaraskan dengan:

1) Pancasila, Undang-Undang Dasar Negara Republik Indonesia Tahun 1945, dan peraturan perundangundangan lain; dan

2) Teknik penyusunan peraturan perundangundangan, dan

b. menghasilkan kesepakatan terhadap substansi yang diatur."

Adapun tahapan untuk melakukan harmonisasi rancangan Perbup pada Bagian Hukum Setda Kabupaten Banggai, adalah sebagai berikut:

1. Pemrakarsa mengajukan draft rancangan Perbup Pemrakarsa menurut Permendagri No. 80 tahun 2015 adalah organisasi perangkat daerah. 
Perangkat daerah pemrakarsa menyusun rancangan Perbup, kemudian disampaikan kepada Bagian Hukum SETDA Kabupaten Banggai.

Sedangkan menurut Farid Hasbullah Karim, Kepala Bagian Hukum Setda Kabupaten Banggai $\begin{array}{llll}\text { (wawancara } & 12 & \text { Juli 2021) }\end{array}$ mengungkapkan "Kalau rancagan Perbup bersifat sektoral berkaitan dgn kewenangan organisasi perangkat daerah, maka organisasi perangkat daerah terkait $\mathrm{yg}$ mengajukan. Manakala rancangan Perbup itu berkaitan dgn lintas sektor misalnya rancangan itu merupakan kewenangan bukan hanya 1 organisasi perangkat daerah saja tetapi ada beberapa, maka di mungkinkan di ajukan/di fasilitasi oleh bagian hukum karena sifatnya lintas sektor."

Berdasarkan uraian tersebut bahwa rancangan peraturan bupati disusun oleh organisasi perangkat daerah terkait, jika perangkat daerah terkait lebih dari satu, maka rancangan Peraturan bupati tersebut difasilitasi atau diajukan oleh bagian Hukum Setda Kabupaten.
2. Pemeriksaan

Draft rancangan peraturan bupati yg di terima oleh Sekretariat Daerah di disposisi ke Bagian Hukum. Selanjutnya Bagian Hukum meneruskan ke Sub Bagian Perundang-undangan untuk dilakukan telaah dan di teliti terkait peraturaan perundang-undangan terkait secara vertikal maupun horizontal, maupun tata cara atau teknik penyusunannya.

Menurut Trasno Kepala Seksi Penyelenggaraan Pemerintahan Desa Dinas Pemberdayaan Masyarakat \& Desa sebagai salah satu pemrakarsa rancangan Perbup (wawancara, 26 Juli 2021) mengatakan bahwa "dinas sebagai pemrakarsa perbup berkoordinasi dengan bagian hukum terkait pembuatan rancangan Perbup. Dinas terkait yang menyusun materi muatan rancangan perbup, setelah itu dilakukan harmonisasi."

Hal tersebut juga dikemukakan oleh Kristopel Satolom, Kepala Seksi Informasi Pasar Kerja dan Penempatan Tenaga Kerja Dinas Tenagakerja dan Transmigrasi (wawancaran, 21 juli 
2021) "Dinas menyusun rancangan

Perbup, kemudian diajukan kepada Bagian Hukum untuk diteliti. Bagian hukum mengembalikan draf rancangan perbup untuk diperbaiki."

Selain itu, bagian hukum mengundang pihak pemrakarsa untuk melakukan rapat bersama untuk melakukan harmonisasi dan membahas isi Rancangan Perbup tersebut. Rancangan Perbup yang telah dilakukan penelitian dan pengkajian, hasilnya dikembalikan lagi kepada kepada pemrakarsa untuk disesuaikan berdasarkan hasil koreksi dari Bagian Hukum

3. Penyampaian hasil harmonisasi rancangan Perbup

Pihak pemrakarsa setelah melakukan perbaikan terhadap hasil harmonisasi, mengajukan rancangan peraturan bupati tersebut kepada Bupati melalui Sekretaris Kabupaten untuk mendapatkan paraf koordinasi.

Hal ini sebagaimana yang diatur pada Pasal 80 ayat (2) Permendagri No.80 Tahun 2015, yaitu "Ketua tim mengajukan rancangan peraturan gubernur dan/atau rancangan peraturan bersama gubernur yang telah mendapat paraf koordinasi sebagaimana dimaksud pada ayat (1) kepada gubernur melalui sekretaris daerah. Pasal tersebut menyebutkan Gubernur, namun berdasarkan Pasal 82 Permendagri No.80 Tahun 2015 bahwa "Ketentuan mengenai pembahasan rancangan peraturan gubernur dan peraturan bersama gubernur sebagaimana dimaksud dalam Pasal 79 sampai dengan Pasal 81 berlaku secara mutatis mutandis terhadap pembahasan rancangan peraturan bupati/walikota dan peraturan bersama bupati/walikota." Berdasarkan uraian tahapan proses harmonisasi rancangan peraturan bupati yang dilakukan oleh Bagian Hukum SETDA Kabupaten Banggai tersebut dapat disimpulkan bahwa pemrakarsa dalam hal ini organisasi perangkat daerah (Dinas atau Badan) menyusun draft rancangan Perbup kemudian diajukan kepada Bagian Hukum untuk dikoreksi dan diharmonisasi terkait dengan keserasian dengan peraturan perundang-undangan terkait dan kesesuaian dengan tata cara penyusunan produk hukum daerah. Setelah itu hasil rancangan 
Perbup yang telah diperbaiki (wawancara, 14 Juli 2021) bahwa diajukan atau disampaikan kepada "proses harmonisasi oleh Bagian Hukum Bupati melalui Sekretaris kabupaten SETDA Kabupaten Banggai terdapat untuk dilakukan paraf koordinasi. beberapa faktor yang mempengaruhi

B. Faktor-faktor

Mempengaruhi

Harmonisasi

Peraturan Bupati oleh Bagian Hukum Sekretariat Daerah

Kabupaten Banggai

Pelaksanaan

Harmonisasi

Rancangan Peraturan Bupati oleh

Bagian Hukum Sekretariat Daerah

Kabupaten Banggai mulai dari tahapan pengajuan draf rancangan peraturan bupati (perbup), pemeriksaan, dan penyampaian hasil perbaikan atas harmonisasi rancangan perbup dilaksanakan sesuai dengan Peraturan Menteri Dalam Negeri Nomor 80 Tahun 2015 Tentang Pembentukan Produk Hukum Daerah, juncto Peraturan Menteri Dalam Negeri Nomor 120 Tahun 2018 tentang Perubahan atas Peraturan Menteri Dalam Negeri Nomor 80 Tahun 2015 tentang Pembentukan Produk Hukum Daerah.

Menurut Rahmawaty Madja Kepala sub Bagian Perundang-undangan dan Implementasi Hukum Bagian Hukum SETDA Kab. Banggai meliputi faktor yang mendukung yaitu faktor hukum, dan koordinasi. Sedangkan faktor penghambat yaitu penguasan materi oleh pemrakarsa dan SDM.”

Adapun faktor-faktor yang mempengaruhi pelaksanaan Harmonisasi Rancangan Peraturan Bupati oleh Bagian Hukum Sekretariat Daerah Kabupaten Banggai, diuraikan berikut ini.

1. Faktor Pendukung

Faktor pendukung pelaksanaan harmonisasi rancangan peraturan bupati oleh Bagian Hukum SETDA Kabupaten Banggai teriri atas:

a. Faktor Hukum

Faktor hukum yang dimaksud adalah keberadaan peraturan perundang-undangan yang memberikan landasan hukum untuk melakukan harmonisasi rancangan peraturan bupati. Adapun peraturan perundang-undang tersebut adalah:

1) Undang-Undang Nomor 12 Tahun $2011 \quad$ tentang 
Pembentukan

Peraturan

Perundang-undangan

2) Undang-Undang Nomor 23 Tahun 2014 tentang Pemerintahan Daerah sebagaimana telah beberapa kali diubah terakhir dengan UndangUndang Nomor 9 Tahun 2015 tentang Perubahan kedua Atas Undang-Undang Nomor 23 Tahun 2014 tentang Pemerintahan

3) Peraturan Menteri Dalam Negeri Nomor 80 Tahun 2015 Tentang Pembentukan Produk Hukum Daerah

4) Peraturan Menteri Dalam Negeri Nomor 120 Tahun 2018 tentang Perubahan atas Peraturan Menteri Dalam Negeri Nomor 80 Tahun 2015 tentang Pembentukan Produk Hukum Daerah

5) Peraturan Daerah Kabupaten Banggai Nomor 4 Tahun 2016 tentang Pembentukan dan Susunan Perangkata daerah Kabupaten Banggai

6) Peraturan Bupati Banggai Nomor 5 Tahun 2017 tentang
Uraian Tugas, Fungsi dan Tata Kerja Sekretariat Daerah

b. Faktor Koordinasi

Faktor koordinasi menjadi hal yang mendukung pelaksanaan harmonisasi rancangan Perbup. Menurut Rahmawaty Madja Kepala sub Bagian Perundang-undangan dan Implementasi Hukum Bagian Hukum SETDA Kab. Banggai (wawancara, 14 Juli 2021), “dalam melakukan harmonisasi rancangan Perbup pemrakarsa melakukan koordinasi dengan kami dalam proses penyusunan, sehingga rancangan yang diajukan sudah banyak yang sesuai dengan materi muatan rancangan perbup." Selain itu koordinasi juga dibangun dengan Biro Hukum Pemerintah Provinsi dan pejabat perancang perundangundangan Kanwil Hukum dan HAM.

2. Faktor Penghambat

$$
\text { Selain faktor pendukung }
$$
terdapat juga faktor yang menghambat pelaksanaan harmonisasi rancangan Perbup oleh Bagian Hukum kabupaten Banggai, yaitu:

a. Faktor Penguasaan Materi oleh Pemrakarsa 


\begin{tabular}{|c|c|}
\hline $\begin{array}{l}\text { Faktor } \\
\text { berpengaruhi }\end{array}$ & $\begin{array}{l}\text { peraturan perundang-undangan dan } \\
\text { kesesuaian teknik penyusunan. }\end{array}$ \\
\hline harmonisasi rancangan Perbup, & b. Faktor Sumber Daya Manusia \\
\hline karena pihak pemrakarsa kurang & (PNS) \\
\hline memahami materi muatan rancangan & Keberadaan sumber \\
\hline perbup yang diajukan. Menurut & manusia dalam hal ini Pegawai \\
\hline Herry Simonsz sebagai Kepala Sub & Negeri Sipil (PNS) yang ada di \\
\hline Bagian Dokumentasi dan Informasi & Bagian Hukum SETDA Kabupaten \\
\hline Bagian Hukum SETDA Kabupaten & Banggai mempengaruhi tugas dan \\
\hline Banggai (wawancara, 16 Juli 2021) & sebagaimana telah \\
\hline bahwa "pemrakarsa kadang tidak & diamanatkan dalam \\
\hline menguasai materi muatan rancangan & Daerah maupun Peraturan Bupati \\
\hline perda yang mereka susun misalnya & tentang uraian tugas dan ungsi \\
\hline ranperbup bppb (badan promosi & Bagian Hukum. Adapun jumlah PNS \\
\hline pariwisata banggai) dari dinas & yang ada pada bagian Hukum \\
\hline pariwisata yang diusulkan judulnya & SETDA Kabupaten Banggai adalah \\
\hline badan promosi pariwisata banggai & 6 orang dengan rincian pendidikan \\
\hline ternyata isi/materi muatannya & Starata Satu (S1) 4 orang dan \\
\hline memuat terkait & pendidikan \\
\hline pengangkatan, & berjumlah 2 orang. Jumlah tersebut \\
\hline angggota badan promosi pariwisata & tentunya sangat sedikit dengan tugas \\
\hline banggai maka judulnya diubah & dan fungsi yang diemban oleh \\
\hline menjadi tata cara pengangkatan, & instansi tersebut. Karena selain tugas \\
\hline pemberhentian angggota badan & harmonisasi rancangan Perbup juga \\
\hline promosi pariwisata banggai." & termasuk rancangan \\
\hline & kum daerah lainnya. \\
\hline
\end{tabular}

proses harmonisasi karena hanya

persoalan judul sudah membutuhkan

\section{Kesimpulan}

analisis, padahal harmonisasi

Pelaksanaan harmonisasi

rancangan peraturan bupati yang dilakukan lebih kepada keserasian

dilakukan oleh Bagian Hukum SETDA Kabupaten Banggai tersebut berawal 
dari pemrakarsa dalam hal ini organisasi perangkat daerah (Dinas atau Badan) menyusun draft rancangan Perbup kemudian diajukan kepada Bagian Hukum untuk dikoreksi dan diharmonisasi terkait dengan keserasian dengan peraturan perundang-undangan terkait dan kesesuaian dengan tata cara penyusunan produk hukum daerah. Setelah itu hasil rancangan Perbup yang telah diperbaiki diajukan atau disampaikan kepada Bupati melalui Sekretaris Kabupaten untuk dilakukan paraf koordinasi. Faktor-faktor yang mempengaruhi pelaksanaan harmonisasi rancangan Peraturan Bupati oleh Bagian Hukum Sekretariat Daerah Kabupaten Banggai meliputi faktor yang mendukung yaitu faktor hukum, dan koordinasi. Sedangkan faktor penghambat yaitu penguasan materi oleh pemrakarsa dan Sumber Daya Manusia atau Pegawai Negeri Sipil (PNS).

\section{Daftar Pustaka}

Dodi Jaya Wardana,2017, Karakteristik Demokrasi Dalam Pembentukan Undang-Undang, UMG Press, Gresik

Faisal Abdullah, 2009, Jalan Terjal Good Governance, Prinsip, Konsep dan Tantangan dalam
Negara Hukum,

PUKAP,

Makassar

Hermi Sari BN, Galang Asmara, Zunnuraeni, 2020,

Pengharmonisasian Rancangan

Peraturan Daerah Inisiatif

Eksekutif oleh Kementerian

Hukum dan Hak Adadi Manusia, Jurnal Dinamika Sosial Budaya, Vol 22, No. 2, Desember 2020

Sudikno Mertokusumo, 2006, Penemuan Hukum (Sebuah Pengantar), Liberty, Yogyakarta. Soegiyono, 2015, Pentingnya Harmonisasi Pembentukan Peraturan Perundang-undangan, Pusat Pengkajian dan Informasi Kedirgantaraan Lembaga Penerbangan dan Antariksa Nasional, Jakarta

Sri Magdalena Hutabalian, 2015, Peran

Biro Hukum Dalam harmonisasi Rancangan Peraturan Daerah (Studi di Biro Hukum SETDA Provinsi Kalimantan Tengah), JISPAR, Jurnal Ilmu Sosial, Politik dan Pemerintahan. Volume 5, Issue 1. ISSN 20896123

Sumber Perundang-undangan : 
Undang-Undang Dasar Negara Republik Indonesia tahun 1945

Undang-Undang Nomor 12 Tahun 2011 tentang Pembentukan Peraturan

Perundang-undangan

Undang-Undang Nomor 23 Tahun 2014

tentang Pemerintahan Daerah sebagaimana telah beberapa kali diubah terakhir dengan Undang-Undang Nomor 9 Tahun 2015 tentang Perubahan kedua Atas Undang-Undang Nomor 23 Tahun 2014 tentang Pemerintahan

Peraturan Menteri Hukum dan Hak Asasi Manusia Nomor 20 tahun 2015 Tentang Tata Cara dan Prosedur Pengharmonisasian, Pembulatan, dan Pemantapan Konsep Rancangan Peraturan Perundang-Undangan
Peraturan Menteri Dalam Negeri Nomor 80 Tahun 2015 Tentang Pembentukan Produk Hukum Daerah

Peraturan Menteri Dalam Negeri Nomor 120 Tahun 2018 tentang Perubahan atas Peraturan Menteri Dalam Negeri Nomor 80 Tahun 2015 tentang Pembentukan Produk Hukum Daerah

Peraturan Daerah Kabupaten Banggai Nomor 4 Tahun 2016 tentang Pembentukan dan Susunan Perangkata daerah Kabupaten Banggai

Peraturan Bupati Banggai Nomor 5 Tahun 2017 tentang Uraian Tugas, Fungsi dan Tata Kerja Sekretariat Daerah 